\title{
Leptin levels in children with obstructive sleep apnea syndrome
}

\author{
Ayhan SÖĞÜT ${ }^{1}$ \\ Şerefden AÇIKGÖZ ${ }^{2}$ \\ Lokman UZUN ${ }^{3}$ \\ Mehmet Birol UĞUR ${ }^{3}$ \\ Remzi ALTIN ${ }^{4}$ \\ Elif DAĞLI ${ }^{5}$ \\ Athanasios KADITIS 6 \\ Refika ERSU ${ }^{5}$
}

${ }^{1}$ Department of Child Health and Diseases, Faculty of Medicine, Bulent Ecevit University, Zonguldak, Turkey

${ }^{1}$ Bülent Ecevit Üniversitesi Tıp Fakültesi, Çocuk Sağlığı ve Hastalıkları Anabilim Dalı, Zonguldak, Türkiye

2 Department of Biochemistry, Faculty of Medicine, Bulent Ecevit University, Zonguldak, Turkey

2 Bülent Ecevit Üniversitesi Tıp Fakültesi, Biyokimya Anabilim Dalı, Zonguldak, Türkiye

${ }^{3}$ Department of Otorhinolaryngology, Faculty of Medicine, Bulent Ecevit University, Zonguldak, Turkey

${ }^{3}$ Bülent Ecevit Üniversitesi Tıp Fakültesi, Kulak Burun Boğaz Anabilim Dalı, Zonguldak, Türkiye

${ }^{4}$ Department of Chest Diseases, Faculty of Medicine, Bulent Ecevit University, Zonguldak, Turkey

${ }^{4}$ Bülent Ecevit Üniversitesi Tıp Fakültesi, Göğüs Hastalıkları Anabilim Dalı, Zonguldak, Türkiye

${ }^{5}$ Department of Pediatric Chest Diseases, Faculty of Medicine, Marmara University, Istanbul, Turkey

${ }^{5}$ Marmara Üniversitesi Tıp Fakültesi, Çocuk Göğüs Hastalıkları Bilim Dalı, Istanbul, Türkiye

${ }^{6}$ Department of Pediatrics, Division Pediatric Pulmonology, School of Medicine and Aghia Sophia Children's Hospital, Athens, Greece

${ }^{6}$ Aghia Sopia Çocuk Hastanesi Tıp Okulu, Çocuk Sağlığı ve Çocuk Hastalıkları Anabilim Dalı, Çocuk Göğüs Hastalıkları Bilim Dalı, Atina, Yunanistan

\section{SUMMARY}

Leptin levels in children with obstructive sleep apnea syndrome

Introduction: The aim of this study is to assess the effect of obstructive sleep apnea syndrome (OSAS) severity on leptin levels in children.

Patients and Methods: Children with habitual snoring underwent overnight polysomnography. Fasting venous blood samples were obtained between 8 AM and 9 AM, following the night of the sleep study. Children with an apnea-hypopnea index of $\geq 5 / h$ were included in the moderate-to-severe OSAS group while those with an apnea-hypopnea index of $<5 / \mathrm{h}$ formed the mild OSAS/primary snoring group.

\section{Yazışma Adresi (Address for Correspondence)}

Results: 47 children (51\% male and $49 \%$ female; mean age $7.8 \pm$ 2.6 years) were recruited. Twenty seven participants were diagnosed with moderate-to-severe OSAS, and twenty children who had AHI $<5$ were included in the mild OSAS/primary snoring. The two

Dr. Ayhan SÖĞÜT

Büyükoyumca Mahallesi Toplukonut Bulvarı Gülşehir Sitesi, No: 121 Atakum, SAMSUN - TURKEY

e-mail: sogutayhan29@hotmail.com 
groups did not differ regarding age, gender and body mass index z score ( $p>0.05)$. Furthermore there were no differences in log serum leptin levels $(p=0.749)$. Log serum leptin levels correlated with the BMI z score in the whole study group $(p=0.001 ; r=0.499)$ but they were not associated with apnea-hypopnea index, mean and lowest oxygen saturation during sleep.

Conclusion: Serum leptin levels are affected by adiposity but not by OSAS severity among children with habitual snoring.

Key words: Leptin, obstructive sleep apnea syndrome, children, sleep apnea

\section{ÖZET}

\section{Obstrüktif uyku apne sendromlu çocuklarda leptin seviyeleri}

Giriş: Bu çalışmanın amacı çocuklarda leptin seviyeleri üzerinde obstrüktif uyku apne sendromu (OUAS)'nun etkisini değerlendirmektir.

Hastalar ve Metod: Habitual horlaması olan çocuklara polisomnografi yapıldı. Uyku çalışmasını takip eden sabah 08.00-09.00 saatleri arasında açlık venöz kan alındı. Apne-hipopne indeksi $\geq 5 /$ saat olan çocuklar orta-ciddi OUAS, <5/saat olan çocuklar hafif OUAS/ primer horlama grubuna alındı.

Bulgular: Çalışmaya 47 çocuk (\%51 erkek ve \% 49 kız; yaş ortalaması $7.8 \pm 2.6$ yıl) alındı. Yirmi yedi çocuk orta-ciddi OUAS, hafif OUAS/primer horlama grubunda yer aldı. Iki grup arasında yaş, cinsiyet ve vücut kitle indeksi açısından anlamlı fark yoktu ( $p>0.05$ ). Log serum leptin seviyeleri gruplar arasında farklı değildi $(p=0.749)$. Çalışma grubunun tümünde log leptin seviyeleri BMI z skoru ile pozitif korelasyon gösterdi $(p=0.001 ; r=0.499)$, fakat log leptin seviyeleri apne-hipopne indeksi, ortalama ve en düşük oksijen satürasyonu ile korelasyon göstermedi.

Sonuç: Habitual horlaması olan çocuklarda serum leptin seviyeleri yă̆ dokusundan etkilenmektedir fakat OUAS şiddetinden etkilenmemektedir.

Anahtar kelimeler: Leptin, tıkayıı uyku apne sendromu, çocuklar, uyku apne

\section{INTRODUCTION}

Obstructive sleep apnea syndrome (OSAS) in children is characterized by prolonged partial upper airway obstruction and/or intermittent complete obstruction that disrupts normal ventilation during sleep and normal sleep patterns (1). OSAS has been associated with metabolic and vascular consequences resulting from increased sympathetic activation, vascular endothelial dysfunction, oxidative stress, inflammation, increased coagulability, and metabolic dysregulation (2-4).

Leptin is a $16 \mathrm{kDa}$ polypeptide cytokine that is released mainly by adipocytes. It inhibits feeding, increases sympathetic activation, modulates immune functions, influences synaptic activities, and often promotes inflammation. The intrinsic circadian rhythm of blood leptin is modulated by gender, development, feeding, fasting, sleep, obesity, and endocrine disorders (5).

In various studies performed in adults, a wide variation of plasma or serum leptin concentrations has been found in patients with OSAS. Leptin concentrations in patients with OSAS have been reported to be higher, at the same level, and even lower when compared with control participants (6-11). A limited number of studies have measured leptin concentrations in children with OSAS. They have demonstrated that leptin concentrations in subjects with OSAS patients were higher or similar to those of participants without OSAS (12-14). The objective of the present report was to assess the association between serum leptin levels and and OSAS severity and to explore the effect of adiposity.

\section{PATIENTS and METHODS}

\section{Subjects}

Children with habitual snoring were included in the study. Demographic data were collected and a complete physical examination, including neurologic, cardiopulmonary, and ear, nose, and throat evaluations was performed. Height and weight were measured using standard techniques for each child. Body mass index (BMI) was calculated as weight/height ${ }^{2}\left(\mathrm{~kg} / \mathrm{m}^{2}\right)$ and BMI z-scores for age and sex were determined based on growth charts for Turkish children $(15,16)$. Participants were classified as obese if their BMI z-score was $\geq 1.65$.

Children with any of the following conditions were excluded from participation: neuromuscular disease, cardiopulmonary disease, anatomic airway obstruction, anatomic maxillomandibular skeletal abnormalities, and respiratory or systemic infections. 


\section{Polysomnography}

All subjects underwent an overnight sleep study to diagnose OSAS. All children were free of upper respiratory infections at the time of polysomnography. Overnight polysomnography (Compumedics E-series, 44 channel, USA) was performed one hour before their usual bedtime. A total of sixteen parameters were recorded. Six electroencephalographic leads (bilateral frontal, central, and occipital), bilateral electro-oculographic leads and submental electromyographic leads were applied in order to identify sleep stages, including time spent in rapid eye movement (REM) sleep. Motion of the chest wall and abdomen was recorded by respiratory inductance plethysmography. Airflow from the nose and mouth was detected with thermocouples and oxygen saturation of hemoglobin was measured by pulse oximetry and cardiac rhythm was monitored with standard electrocardiographic leads. Body motion was recorded with pretibial electromyographic leads.

Obstructive apnea was defined as absent airflow in the presence of respiratory effort for the duration of at least two respiratory cycle. Hypopnea was defined as a $30 \%$ reduction in airflow with synchronous chest wall and abdominal motion for the duration of at least two respiratory cycles, resulting in either arousal or oxyhemoglobin desaturation of at least $3 \%$ (17). The type, number, and duration of respiratory events were noted, as well as the median and minimum oxygen saturation of hemoglobin $\left(\mathrm{SpO}_{2}\right)$. The apnea/hypopnea index (AHI) was calculated as (number of obstructive apnea events plus number of hypopnea events) per hour of total sleep time. Moderate-to-severe OSAS was diagnosed when the $\mathrm{AHI}$ was $\geq 5 / \mathrm{h}$ and mild OSAS/primary snoring when the $A H I$ was $<5 / h$.

\section{Leptin Measurements}

Fasting venous blood samples were obtained between $8 \mathrm{AM}$ and $9 \mathrm{AM}$, following the night of the sleep study. Blood samples were centrifuged and sera were stored immediately at $-70 \mathrm{C}$ until measurement of leptin. Levels of leptin were determined using the Human leptin ELISA kit (DSL, Diagnostic Systems Laboratories, Inc. Texas, USA) with an enzymatically amplified 'two step' sandwich - type immunoassay in LP 400 ELISA device (Pasteur Diagnostics, France). The calibration curve was prepared with leptin standarts as $0-50 \mathrm{ng} / \mathrm{mL}$.

\section{Statistical Analysis}

Statistical analysis was carried out using a statistical software package (Version 11.0 for Windows; SPSS; Chicago, USA). Children were grouped as moderateto-severe OSAS (AHI $\geq 5 / h$ ) and mild OSAS/primary snoring $(\mathrm{AHI}<5 / \mathrm{h})$. The normality test of the data was performed through Shapiro Wilk. Normally distributed data are presented as mean \pm standard deviation while those not normally distributed are presented as median (min-max) values. Independent sample t-test and Mann-Whitney U-test were applied for the analysis of continuous data and Chi-square test was used for the analysis of categorical data. The association between the variables was explored through Spearman's correlation analysis. Since the leptin levels did not show normal distribution, logarithmic transformation was performed to achieve a normal distribution. No transformation was required for other variables (BMI z score, $\mathrm{AHI}$ ). $\mathrm{P}<0.05$ was considered significant.

\section{Ethical Approval}

This study was approved by the Ethics Committee of Zonguldak Karaelmas University School of Medicine. Written informed consent was obtained from parents of the children who participated in the study.

\section{RESULTS}

Fourty seven children ( $51 \%$ male and $49 \%$ female) were included in the study. Twenty seven children had moderate-to-severe OSAS, and twenty children were diagnosed with mild OSAS/primary snoring (Table 1). The two study groups did not differ in terms of age, gender or BMI z score ( $p>0.05)$. Serum leptin levels were $32.8 \pm 38.6 \mathrm{ng} / \mathrm{mL}$ in subjects with moderate-to-severe OSAS and $36.0 \pm 37.6 \mathrm{ng} / \mathrm{mL}$ in those with mild OSAS/primary snoring. There was no significant difference in log plasma leptin levels between the two groups $(p=0.749)$ (Table 1).

Log plasma leptin levels correlated significantly with the BMI z score in the whole study group $(p=0.001$ $r=0.499$ ) (Figure 1). No significant correlation was identified between log serum leptin levels and $\mathrm{AHI}$ $(r=0.119 ; p=0.42)$, mean and lowest $\mathrm{SpO}_{2}$ during sleep $(r=-0.052 ; p=0.72$ and $r=-0.011 ; p=0.94$, respectively). 
Table 1. Demographic characteristics, polysomnography findings and leptin serum levels in children with moderate-to-severe OSAS or mild OSAS/primary snoring

\begin{tabular}{|lccc} 
Characteristics & $\begin{array}{c}\mathbf{A H I}<\mathbf{5} / \mathbf{h} \\
(\mathbf{n = 2 0})\end{array}$ & $\begin{array}{c}\mathbf{A H I} \geq \mathbf{5} / \mathbf{h} \\
(\mathbf{n = 2 7})\end{array}$ & $\mathbf{p}$ \\
\hline Age, years & $8.25 \pm 2.33$ & $7.44 \pm 2.81$ & 0.302 \\
Male/female, \% & $55 / 45$ & $48.1 / 51.9$ & 0.865 \\
$\mathrm{BMI}$ z score & $0.12 \pm 1.27$ & $0.52 \pm 1.37$ & 0.324 \\
$\mathrm{AHI} / \mathrm{h}$ & $1.5(0.00-4.30)$ & $10(5-37)$ & 0.001 \\
Lowest $\mathrm{SpO}_{2}, \%$ & $74(50-93)$ & $84(50-92)$ & 0.923 \\
Mean $\mathrm{SpO}_{2}, \%$ & $96(72-98)$ & $97(72-98)$ & 0.275 \\
Log leptin & $1.34 \pm 0.44$ & $1.30 \pm 0.43$ & 0.749 \\
\hline Variables are presented as mean \pm standard deviation or median (minimum-maximum). & \\
\hline
\end{tabular}

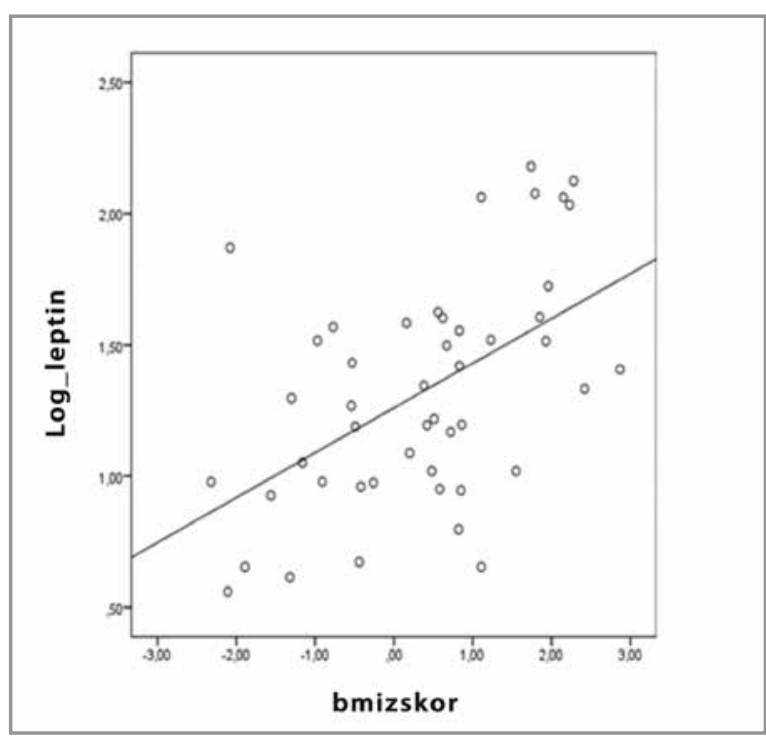

Figure 1. Correlation of log plasma leptin levels and body mass index z score.

\section{DISCUSSION}

The present study indicates that serum leptin levels in children with snoring are not affected by OSAS severity. Indeed, serum leptin levels did not correlate with any polysomnography parameters. In contrast, serum leptin levels correlated with the degree of adiposity as expressed by BMI z score.

Studies in adults with OSAS reported that leptin levels were higher, lower or not different from those of subjects without OSAS (6-11). In most of the studies which reported hyperleptinemia in patients with OSAS, the relationship between OSAS and high leptin levels was independent of the body mass index (5). When two groups of patients with OSAS and non-OSAS with similar body masss indexes were compared, leptin levels were higher in the former group (18). However, some studies did not demonstrate such a relationship. Blood leptin in the morning did not differ among 21 non-obese patients with OSAS, 20 non-obese controls, 28 obese patients with OSAS, and 10 obese controls without OSAS (19). Obesity alone was associated with hyperleptinemia even in the absence of OSAS (19). In addition, other investigators have indicated that leptin concentrations in patients with OSAS and morbid obesity were lower than those of patients with morbid obesity but without OSAS (11).

It should be kept in mind that many factors such as sampling methods, eating habits, duration of sleep and circadian rhythm can modulate leptin concentration (5). In addition, blood leptin levels in OSAS patients are affected by the presence or absence of obesity. Barcelo et al. reported that obesity had a greater contribution to hyperleptinemia than OSAS (20).

In pediatric studies, leptin levels of patients with OSAS were reported to be higher or the same when compared to participants without OSAS (12-14). Tauman et al. reported that plasma leptin levels were significantly elevated in children with sleepdisordered breathing independent of obesity (12). In that study, 130 children (mean age $8.2 \pm 2.8$ years; $39 \%$ obese) were included. The age range of the sample population was wide, ranging from 1 to 17 years, with a mean age of 8.2 years. Children with an $\mathrm{AHI}>1$ but $<5 / \mathrm{h}$ were considered to have mild $\mathrm{SDB}$, while children with $\mathrm{AHI}>5 / \mathrm{h}$ were considered to have moderate-to-severe SDB. Leptin levels in 85 children with $\mathrm{AHI}>1$ were compared to 45 children with $\mathrm{AHI} \leq 1$. And plasma leptin levels were significantly elevated in the former. Leptin levels in children with $\mathrm{SpO}_{2}$ nadir $\geq 90 \% \quad$ ("minimal 
hypoxemia"), $\mathrm{SpO}_{2}$ nadir of $80 \%-89 \%$ ("moderate hypoxemia"), and $\mathrm{SpO}_{2}$ nadir $<80 \%$ ("severe hypoxemia") were also compared. Leptin levels were significantly lower in children in "minimal hypoxemia" group when compared to the two other groups (12).

Nakra et al. found an association between sleepdisordered breathing in obese children with metabolic syndrome and leptin levels (14). Treatment of sleep-disordered breathing with continuous positive airway pressure led to a significant decrease in leptin levels. Study population included 34 children. The age range of their sample population was from 7 to 19 years (mean age 8.2 years) and sleep-disordered breathing was diagnosed if subjects had an $\mathrm{AHI} \geq 1.5 / \mathrm{h}$ (14).

$\mathrm{Li}$ et al. reported that leptin levels in children were more closely associated with obesity than with OSAS severity (13). Leptin levels were not different between subjects with and without OSAS. OSAS was diagnosed if the obstructive apnea index was $>1 / \mathrm{h}$. One hundred forty-one children, of whom 96 were boys, with a median (interquartile range) age of 10.8 (8.5-12.8) years were recruited and 43 of them had OSAS. The study population consisted of nonobese subjects without OSAS, nonobese subjects with OSAS, obese subjects without OSAS, and obese subjects with OSAS. Sixteen children with OSAS underwent CPAP treatment and there was a trend of increased leptin levels following treatment (13).

The age range of our patients was similar to the age distribution of patients in the study by Tauman et al. The frequency of obesity was $21 \%$ in this report as compared to $39 \%$ in the study by Tauman et al, $100 \%$ in the report by Nakra et al. study and 59\% in the investigation by $\mathrm{Li}$ et al (12-14). We have found that serum leptin levels were similar in children with and without OSAS and that serum leptin levels correlated with the BMI z score in the whole study group. Thus our results consistent with those by Li et al.

There were some limitation in our study. Firstly, our patient population was relatively small. Secondly, subjects without snoring were not recruited.

In conclusion, serum leptin levels are not affected by OSAS severity in children with snoring and they are mainly affected by the degree of adiposity.

\section{CONFLICT of INTEREST}

All authors certify that they have no affiliations with or involvement in any organization or entity with any financial interest (such as honoraria; educational grants; participation in speakers' bureaus; membership, employment, consultancies, stock ownership, or other equity interest; and expert testimony or patent-licensing arrangements), or nonfinancial interest (such as personal or professional relationships, affiliations, knowledge or beliefs) in the subject matter or materials discussed in this manuscript.

\section{REFERENCES}

1. American Thoracic Society. Standards and indications for cardiopulmonary sleep studies in children. Am J Respir Crit Care Med 1996;153:866-78.

2. Shamsuzzaman AS, Gersh BJ, Somers VK. Obstructive sleep apnea: implications for cardiac and vascular disease. I Am Med Assoc 2003;290:1906-14.

3. McArdle N, Hillman D, Beilin L, Watts G. Metabolic risk factors for vascular disease in obstructive sleep apnea: a matched controlled study. Am J Respir Crit Care Med 2007; 175:190-5

4. Seif F, Patel SR, Walia H, Rueschman M, Bhatt DL, Gottlieb $D$, et al. Association between obstructive sleep apnoea severity and endothelial dysfunction in an increased background of cardiovascular burden. I Sleep Res 2013;22:443-51.

5. Pan W, Kastin AJ. Leptin: A biomarker for sleep disorders? Sleep Medicine Reviews 2014; 18:283-90.

6. Basoglu OK, Sarac F, Sarac S, Uluer H, Yilmaz C. Metabolic syndrome, insulin resistance, fibrinogen, homocysteine, leptin, and C-reactive protein in obese patients with obstructive sleep apnea syndrome. Ann Thorac Med 2011;6:120-5.

7. Ulukavak CT, Kokturk O, Bukan N, Bilgihan A. Leptin and ghrelin levels in patients with obstructive sleep apnea syndrome. Respiration 2005;72:395-401.

8. Ursavas A, I/col YO, Nalci N, Karadag M, Ege E. Ghrelin, leptin, adiponectin, and resistin levels in sleep apnea syndrome: role of obesity. Ann Thorac Med 2010;5:161-5.

9. Sharma SK, Kumpawat S, Goel A, Banga A, Ramakrishnan L, Chaturvedi P. Obesity, and not obstructive sleep apnea, is responsible for metabolic abnormalities in a cohort with sleep-disordered breathing. Sleep Med 2007;8:12-7.

10. Kapsimalis F, Varouchakis G, Manousaki A, Daskas S, Nikita $D$, Kryger $M$, et al. Association of sleep apnea severity and obesity with insulin resistance, C-reactive protein, and leptin levels in male patients with obstructive sleep apnea. Lung 2008;186:209-17. 
11. Fredheim JM, Rollheim I, Omland T, Hofso D, Roislien J, Vegsgaard $K$, et al. Type 2 diabetes and pre-diabetes are associated with obstructive sleep apnea in extremely obese subjects: a cross-sectional study. Cardiovasc Diabetol 2011;10:84.

12. Tauman $R$, Serpero $L D$, Capdevila OS, O'Brien $L M$, Goldbart $A D$, Gozal- Kheirandish L, et al. Adipokines in children with sleep disordered breathing. Sleep 2007;30:443-9.

13. Li AM, Ng C, Ng SK, Chan MM, So HK, Chan l, et al. Adipokines in children with obstructive sleep apnea and the effects of treatment. Chest 2010;137:529-35.

14. Nakra N, Bhargava S, Dzuira J, Caprio S, Bazzy-Asaad A. sleep-disordered breathing in children with metabolic syndrome: the role of leptin and sympathetic nervous system activity and the effect of continuous positive airway pressure. Pediatrics 2008;122;634-42.

15. Gökçay G, Furman A, Neyzi O. Updated growth curves for Turkish children aged 15 days to 60 months. Child Care Health Dev 2008;34:454-63.
16. Bundak R, Furman A, Gunoz H, Darendeliler F, Bas F, Neyzi $O$. Body mass index references for Turkish children. Acta Paediatr 2006;95:194-8.

17. Brunetti L, Rana S, Lospalluti ML, Pietrafesa A, Francavilla R, Fanelli $M$, et al. Prevalence of obstructive sleep apnea syndrome in a cohort of 1,207 children of southern Italy. Chest 2001;120:1930-5.

18. Tatsumi K, Kasahara Y, Kurosu K, Tanabe N, Takiguchi Y, Kuriyama T. Sleep oxygen desaturation and circulating leptin in obstructive sleep apneahypopnea syndrome. Chest 2005; 127:716-21.

19. Sánchez-de-la-Torre M, Mediano O, Barceló A, Piérola J, de la Peña $M$, Esquinas $C$, et al. The influence of obesity and obstructive sleep apnea on metabolic hormones. Sleep Breath 2012; 16:649-56.

20. Barceló A, Barbé F, Llompart E, de la Peña $M$, DuránCantolla J, Ladaria A, et al. Neuropeptide $Y$ and leptin in patients with obstructive sleep apnea syndrome: role of obesity. Am J Respir Crit Care Med 2005;171:183-7. 